DOI: $10.15193 /$ zntj/2018/117/267

\author{
AGNIESZKA PALKA, MAGDA ŚNIEGOCKA-DWORAK, \\ ALEKSANDRA WILCZYŃSKA
}

\title{
SPRZEDAŻ BEZPOŚREDNIA A BEZPIECZEŃSTWO ŻYWNOŚCI POCHODZENIA ZWIERZĘCEGO NA PRZYKLADZIE PRAKTYK W POWIECIE TCZEWSKIM
}

\begin{abstract}
Streszczenie
Na rynku spożywczym dominują produkty wysoko przetworzone. Szeroka oferta produktów żywnościowych sprawia, że konsumenci są bardziej wymagający i dokonują zakupów z większą świadomością. Poszukują żywności atrakcyjnej sensorycznie, o sprawdzonym źródle pochodzenia, spełniającej wymagania dotyczące bezpieczeństwa, w tym stosowanych substancji dodatkowych oraz ich dozwolonych ilości, poziomów substancji zanieczyszczających, pozostałości pestycydów, warunków napromieniania żywności, po działania podejmowane w trakcie produkcji czy obrotu żywnością, których celem jest przede wszystkim zapewnienie, aby żywność była bezpieczna dla ludzkiego zdrowia i życia. Wymagania te powinna również spełniać żywność sprzedawana w systemie sprzedaży bezpośredniej. Zgodnie z definicją żywność ta jest produkowana z surowców własnych podmiotu prowadzącego działalność wytwórczą i przeznaczona do sprzedaży bezpośredniej. Przedmiotem niniejszej pracy była analiza wymogów formalnych dotyczących sprzedaży bezpośredniej produktów spożywczych w celu określenia, czy aktualnie obowiązujący system prawny zapewnia bezpieczeństwo żywności sprzedawanej bezpośrednio. Przeprowadzono wywiad z pracownikiem Powiatowego Inspektoratu Weterynarii w Tczewie oraz pilotażowe badanie ankietowe wśród dziesięciu celowo dobranych producentów z terenu powiatu tczewskiego. Respondenci stanowili 34 \% producentów żywności pochodzenia zwierzęcego sprzedawanej bezpośrednio. Kwestionariusz ankietowy składał się z pytań o datę rejestracji działalności, sposoby zapewnienia bezpieczeństwa wytwarzanym produktom oraz częstotliwość kontroli Inspekcji Weterynaryjnej. Wykazano, że zarówno system prawny, sposób wytwarzania, jak i system kontroli gwarantuje bezpieczeństwo tego rodzaju żywności w badanej grupie. Obserwacje z badań pilotażowych posłużą do przeprowadzenia analogicznych badań na większej, reprezentatywnej grupie respondentów.
\end{abstract}

Słowa kluczowe: sprzedaż bezpośrednia, zapewnienie bezpieczeństwa żywności, kontrola, Inspekcja Weterynaryjna

Dr inż. A. Palka, mgr inż. M. Śniegocka-Dworak, dr hab. inż. A. Wilczyńska, prof. nadzw., Katedra Towaroznawstwa i Zarządzania Jakościa, Wydz. Przedsiębiorczości i Towaroznawstwa, Uniwersytet Morski w Gdyni, ul. Morska 81-87,81-225 Gdynia.Kontakt: a.palka@wpit.umg.edu.pl 


\section{Wprowadzenie}

Rynek spożywczy, zarówno krajowy, jak i zagraniczny jest zdominowany przez produkty wysoko przetworzone. Do tej kategorii produktów należą m.in. wysoko przetworzone wędliny, dania gotowe, dania do szybkiego przygotowania. Produkty często wytwarzane są z półproduktów, zawierają substancje konserwujące, barwniki oraz innego rodzaju dodatki do żywności. Stanowią asortyment produktów o niższej jakości. Konsumenci coraz częściej podążają za modą na bycie w dobrej formie fizycznej oraz wyznają zasady zdrowego odżywiania się, dlatego poszukują żywności wysokiej jakości, w jak najmniejszym stopniu przetworzonej, o sprawdzonym źródle pochodzenia. Żywność ta winna również być bezpieczna, począwszy od spełnienia wymagań dotyczących cech organoleptycznych, stosowanych substancji dodatkowych oraz ich dozwolonych ilości, poziomów substancji zanieczyszczających, pozostałości pestycydów i warunków napromieniania żywności, po działania podejmowane w trakcie produkcji żywności czy obrotu nią. Działania te mają przede wszystkim na celu zapewnienie zdrowia oraz dobrej kondycji człowieka. Bogata oferta oraz nowe trendy w żywieniu sprawiają, że nabywcy żywności stają się bardziej wymagający i dokonują zakupów z większą świadomością, coraz częściej w sprzedaży bezpośredniej i często wybierają produkty regionalne i tradycyjne. Tego typu produkty spożywcze zazwyczaj są oceniane w zakresie identyfikacji, oznaczenia, rejestracji, promocji itp. Temat bezpieczeństwa i jakości takich wyrobów w powszechnej opinii wydaje się mniej istotny, chociaż mogą w nich występować zarówno wady jakościowe, jak i zanieczyszczenia zagrażające zdrowiu konsumentów. Związane jest to z wytwarzaniem produktów w gospodarstwie, w którym trudniej jest zapewnić odpowiednie warunki higieniczne oraz powtarzalne parametry procesu technologicznego $\mathrm{w}$ porównaniu $\mathrm{z}$ warunkami $\mathrm{w}$ wyspecjalizowanych zakładach produkcyjnych $[3,14]$.

Jedną z form sprzedaży, która gwarantuje sprawdzone źródło pochodzenia oraz zapewnia świeżość i niski stopień przetworzenia żywności, jest sprzedaż bezpośrednia, czyli sprzedaż produktów rolniczych wytworzonych w gospodarstwie bezpośrednio do odbiorcy finalnego, z pominięciem pośredników. Stanowi ona wykorzystywany od dawna kanał dystrybucji w rolnictwie, pozwalający na powiększenie dochodów rolnika. Sprzedaż bezpośrednia prowadzona przez rolników posiadających małe gospodarstwa, często ekologiczne oraz agroturystyczne, jest często spotykaną formą sprzedaży w Europie Zachodniej, np. w Austrii, Niemczech czy w Szwajcarii, gdzie konsumentom zależy na spożywaniu żywności bezpiecznej i ekologicznej. Sprzedażą bezpośrednią produktów pochodzenia zwierzęcego w 2014 roku zajmowały się w Polsce 6774 podmioty, a w październiku 2016 roku zarejestrowanych było już 8387 rolników prowadzących sprzedaż bezpośrednią, ograniczającą się do kilku rodzajów produktów pochodzenia zwierzęcego $[2,13]$. 
Sprzedaż bezpośrednia żywności występuje wówczas, gdy żywność ta jest wyprodukowana z surowców własnych podmiotu prowadzącego działalność wytwórczą. Ustawodawstwo krajowe definiuje sprzedaż bezpośrednią na podstawie art. 1 Rozporządzenia 852/2004 Parlamentu Europejskiego i Rady z dnia 29 kwietnia 2004 r. w sprawie higieny środków spożywczych [6]. Na tej podstawie ustanowiono poszczególne przepisy dotyczące higieny w odniesieniu do żywności pochodzenia zwierzęcego, działalności w zakresie bezpośrednich dostaw dokonywanych przez producenta do konsumentów końcowych lub lokalnego zakładu detalicznego zaopatrującego bezpośrednio odbiorców końcowych. Dotyczy to również dostaw bezpośrednich małych ilości mięsa $\mathrm{z}$ drobiu lub zajęczaków, poddanych ubojowi w gospodarstwie rolnym, dokonywanych przez producenta do konsumenta końcowego lub lokalnego zakładu detalicznego, bezpośrednio dostarczającego przedmiotowe świeże mięso konsumentowi końcowemu. Tego rodzaju dostawy mogą być również dokonywane przez myśliwych w postaci małych ilości zwierzyny łownej lub mięsa zwierząt łownych bezpośrednio do konsumenta końcowego lub lokalnego zakładu detalicznego bezpośrednio zaopatrującego konsumenta końcowego.

Produkcja żywności przeznaczonej do sprzedaży bezpośredniej powinna spełniać wymagania zawarte w Rozporządzeniu 178/2002 Parlamentu Europejskiego i Rady z dnia 28 stycznia 2002 r. ustanawiającym ogólne zasady i wymagania prawa żywnościowego, powołującym Europejski Urząd ds. Bezpieczeństwa Żywności oraz ustanawiającym procedury w zakresie bezpieczeństwa żywności [5] oraz w przepisach unijnych (tzw. pakiecie higienicznym), którymi są:

- Rozporządzenie 852/2004 Parlamentu Europejskiego i Rady z dnia 29 kwietnia 2004 r. w sprawie higieny środków spożywczych [6],

- Rozporządzenie 853/2004 Parlamentu Europejskiego i Rady z dnia 29 kwietnia 2004 r. ustanawiające szczególne przepisy dotyczące higieny w odniesieniu do żywności pochodzenia zwierzęcego [7],

- Rozporządzenie 854/2004 Parlamentu Europejskiego i Rady z dnia 29 kwietnia 2004 r. ustanawiające szczególne przepisy dotyczące organizacji urzędowych kontroli $\mathrm{w}$ odniesieniu do produktów pochodzenia zwierzęcego przeznaczonych do spożycia przez ludzi [8].

$\mathrm{W}$ prawie krajowym zagadnienia te regulują:

- Ustawa z dnia 16 grudnia 2005 r. o produktach pochodzenia zwierzęcego [16],

- Ustawa z dnia 25 sierpnia 2006 r. o bezpieczeństwie żywności i żywienia [17],

- Rozporządzenie Ministra Rolnictwa i Rozwoju Wsi z dnia 30 września 2015 r. w sprawie wymagań weterynaryjnych przy produkcji produktów pochodzenia zwierzęcego przeznaczonych do sprzedaży bezpośredniej [11],

- Rozporządzenie Ministra Zdrowia z dnia 6 czerwca 2007 r. w sprawie dostaw bezpośrednich środków spożywczych [9]. 
Przepisy określone w ustawach i rozporządzeniach dotyczących sprzedaży bezpośredniej precyzyjnie wskazują na procedury i sposoby postępowania w celu zapewnienia bezpieczeństwa żywności. Postępowanie producentów zgodnie z wymaganiami oraz nadzór nad podmiotami ze strony organów do tego powołanych pozwala możliwie najpełniej gwarantować bezpieczeństwo wprowadzonych do obrotu produktów w ramach sprzedaży bezpośredniej.

Urzędowym organem właściwym do nadzoru i kontroli działań związanych z produkcją oraz dystrybucją produktów pochodzenia zwierzęcego bez względu na formę handlu jest Powiatowy Inspektorat Weterynarii [15]. Ze względu na tę formę producenci muszą spełniać określone warunki oraz dopełnić formalności związanych z wybranym rodzajem dystrybucji. Powiatowy lekarz weterynarii czuwa nad bezpieczeństwem żywności pochodzenia zwierzęcego dystrybuowanej w drodze:

- rolniczego handlu detalicznego (RHD),

- sprzedaży bezpośredniej (SB),

- działalności marginalnej, lokalnej i ograniczonej (MLO).

Prowadzenie działalności w ramach sprzedaży bezpośredniej zostało określone w art. 21 Ustawy o produktach pochodzenia zwierzęcego [16]. Procedura rejestracyjna jest złożona i wymaga, oprócz złożenia wniosku, również zatwierdzenia przez właściwego miejscowo powiatowego lekarza weterynarii. W pierwszej kolejności należy złożyć projekt technologiczny w formie graficznej oraz opisowej z wnioskiem o jego zatwierdzenie. Część opisowa projektu technologicznego powinna zawierać informacje dotyczące:

- rodzaju działalności, ze wskazaniem produktów pochodzenia zwierzęcego, które będą produkowane w zakładzie,

- maksymalnej tygodniowej zdolności produkcyjnej zakładu,

- systemu dostawy wody - ujęcie własne czy gminne,

- sposobu przechowywania odpadów i ubocznych produktów pochodzenia zwierzęcego,

- lokalizacji zakładu.

Powiatowy lekarz weterynarii zatwierdza projekt technologiczny, po czym zleca kontrolę zgodności projektu z rzeczywistością. Po pozytywnym wyniku wizji lokalnej producent winien, zgodnie $\mathrm{z}$ ustawą [16], w terminie 30 dni przed rozpoczęciem działalności złożyć wniosek do powiatowego lekarza weterynarii o nadanie numeru identyfikacyjnego oraz wpis do rejestru podmiotów nadzorowanych. We wniosku należy zamieścić:

- imię i nazwisko, miejsce zamieszkania i adres,

- numer $\mathrm{w}$ rejestrze przedsiębiorców (KRS) lub numer identyfikacji podatkowej (NIP), 
- określenie rodzaju działalności oraz jej zakres, z wymienieniem produktów pochodzenia zwierzęcego produkowanych przez wnioskodawcę,

- określenie miejsca prowadzenia działalności.

Po uzyskaniu decyzji o wpisie do rejestru oraz nadaniu numeru identyfikacyjnego podmiot jest uprawniony do rozpoczęcia produkcji oraz sprzedaży. Decyzja zawiera potwierdzenie deklarowanego przez wnioskodawcę zakresu działalności oraz ilości sprzedawanych produktów [16].

Celem niniejszego opracowania była ocena, czy obowiązujący system prawny gwarantuje w pełni bezpieczeństwo żywności sprzedawanej bezpośrednio. Cel ten realizowano, przeprowadzając dwutorowe badanie polegające na ocenie działań Inspekcji Weterynaryjnej oraz wybranych producentów żywności sprzedawanej bezpośrednio.

\section{Material i metody badań}

W celu sprawdzenia stosowania przepisów prawa w praktyce przeprowadzono wywiad z pracownikiem Powiatowego Inspektoratu Weterynarii w Tczewie. Zadano pytania dotyczące zakresu kompetencji inspektoratu oraz powiatowego lekarza weterynarii w związku ze sprzedażą bezpośrednią. Zapytano o proces rejestracyjny, badanie jakości, procedury zapewniające bezpieczeństwo żywności oraz działalność kontrolną.

Drugim kierunkiem były badania ankietowe wśród dziesięciu celowo dobranych producentów żywności sprzedawanej bezpośrednio z terenu powiatu tczewskiego. Były to badania pilotażowe, a ich wyniki posłużą do przeprowadzenia analogicznych badań na reprezentatywnej dla większego terenu populacji producentów omawianej żywności. Respondenci to osoby zajmujące się produkcją oraz przetwarzaniem produktów pochodzenia zwierzęcego i zarejestrowane jako podmioty prowadzące działalność $\mathrm{w}$ ramach sprzedaży bezpośredniej. Listę podmiotów uzyskano z oficjalnej strony Głównego Inspektoratu Weterynarii [18]. Badanie prowadzono od lipca do września 2018 roku.

Kwestionariusz ankietowy składał się z metryczki oraz pytań o datę rejestracji działalności, sposoby zapewnienia bezpieczeństwa wytwarzanym produktom oraz częstotliwość kontroli Inspekcji Weterynaryjnej. Metryczka dotyczyła profilu działalności podmiotu. Respondenci zostali poproszeni o zaznaczenie produktu przeznaczonego do sprzedaży bezpośredniej, który zbywają w ramach swojej działalności.

Według wykazu zamieszczonego przez Inspektorat Weterynarii w powiecie tczewskim zarejestrowanych jest 29 podmiotów działających w ramach sprzedaży bezpośredniej, w związku z czym do wypełnienia przygotowano 29 kwestionariuszy ankietowych. Część kwestionariuszy została rozesłana, część przekazana osobiście. Otrzymano 10 prawidłowo wypełnionych ankiet, jedną odpowiedź o zawieszeniu działalności i jedną informację o jej przeniesieniu. 


\section{Wyniki i dyskusja}

\section{Zakres dziatań Inspekcji Weterynaryjnej na przykładzie inspektoratu w Tczewie}

W powiecie tczewskim działalność w zakresie sprzedaży bezpośredniej prowadzi 29 podmiotów. Numer indentyfikacyjny nadawany jest zgodnie z Rozporządzeniem Ministra Rolnictwa i Rozwoju Wsi z dnia 15 grudnia 2016 roku w sprawie sposobu ustalania weterynaryjnego numeru identyfikacyjnego [12]. Zgodnie z rozporządzeniem pierwsze dwie cyfry oznaczają symbol województwa, dwie kolejne to symbol powiatu, cyfry piąta i szósta to symbol zakresu działalności, siódma i kolejne to kolejne numery podmiotów podejmujących działalność. Dla przykładu, podmiotowi podejmującemu działalność w zakresie sprzedaży bezpośredniej w powiecie tczewskim nadawany jest numer 22143529 (rys. 1).

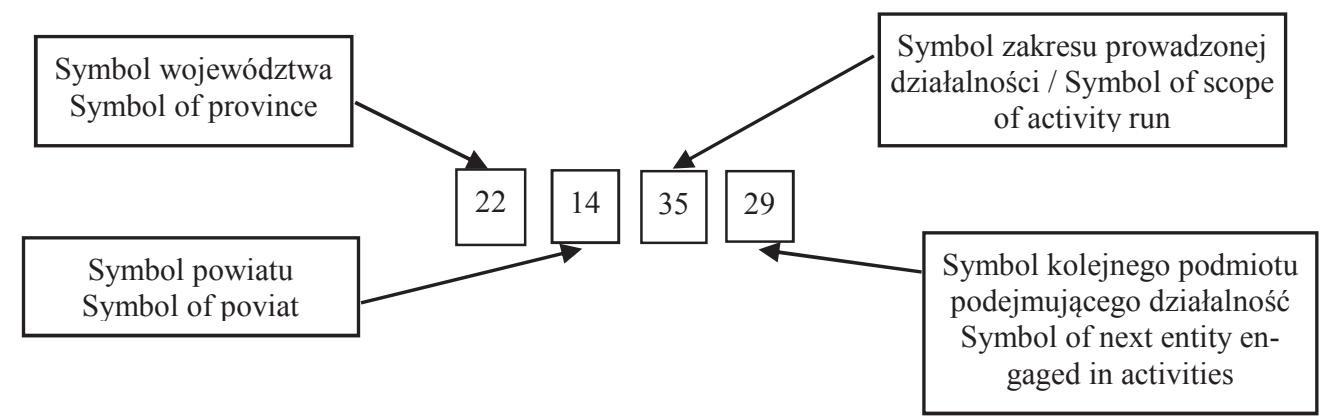

Rys. 1. Weterynaryjny numer identyfikacyjny

Fig. 1. Veterinary identification number

Źródło / Source: opracowanie własne / the author's own study

Żywność pochodzenia zwierzęcego sprzedawana w ramach sprzedaży bezpośredniej powinna być oznaczana zgodnie rozporządzeniem 931/2011 [10], którego przepisy zapewniają możliwość śledzenia żywności oraz umożliwiają dostarczenie właściwemu organowi informacji dotyczących dokładnego opisu żywności, ilości, podmiotu odbierającego żywność, producenta, serii oraz partii żywności.

Podmiot prowadzący sprzedaż bezpośrednią zgodnie z Rozporządzeniem Ministra Rolnictwa i Rozwoju Wsi z dnia 30 września 2015 r. w sprawie wymagań weterynaryjnych przy produkcji produktów pochodzenia zwierzęcego przeznaczonych do sprzedaży bezpośredniej [11] zobowiązuje się prowadzić i przechowywać dokumentację z prowadzonej działalności na potwierdzenie:

1) ilości produktów sprzedawanych $w$ danym tygodniu,

2) wymaganych czynności sprawdzająco-kontrolnych w zakresie: 
- czystości wody pochodzącej z własnego ujęcia (kontrola co najmniej raz w ro$\mathrm{ku})$,

- przestrzegania zasad higieny w procesie produkcyjnym oraz sprzedaży,

- posiadania przez personel mający styczność z produktami pochodzenia zwierzęcego zaświadczeń lekarskich do celów sanitarno-epidemiologicznych,

- przeprowadzonych badań żywności zgodnie z harmonogramem przedstawionym powiatowemu lekarzowi weterynarii.

Dokumenty dotyczące produkcji, dystrybucji oraz działań samokontrolnych zgodnie z ww. rozporządzeniem [11] należy przechowywać przez jeden rok od zakończenia poprzedniego okresu rocznego. Natomiast potwierdzenie odbioru ubocznych produktów pochodzenia zwierzęcego należy przechowywać do celów kontrolnych co najmniej przez dwa lata.

Urzędowe kontrole produktów pochodzenia zwierzęcego przeprowadza powiatowy lekarz weterynarii zgodnie z ustawą o produktach pochodzenia zwierzęcego [16]. Kontrola odbywa się zgodnie z wytycznymi powiatowego lekarza weterynarii co najmniej raz na dwa lata. Inspektor przeprowadzający kontrolę prowadzi dyskusję z podmiotem prowadzącym działalność i sporządza z niej protokół. Przed kontrolą należy podmiot pouczyć o jego prawach i obowiązkach oraz o możliwościach wniesienia zastrzeżeń do protokołu w ciągu 7 dni od zakończenia kontroli. Przedmiotem kontroli są przede wszystkim: stan faktyczny gospodarstwa, warunki sanitarno-higieniczne, dokumentacja. W razie stwierdzenia uchybień wpisanych do protokołu zostaje wszczęte postępowanie administracyjne. Wydanie decyzji administracyjnej nakazującej usunięcie uchybień następuje po 14 dniach od wszczęcia postepowania. Termin do usunięcia niezgodności wynosi 7 dni. Po wyznaczonym terminie przeprowadzana jest rekontrola, czyli kontrola sprawdzająca. Gdy kontrola sprawdzająca nie wykaże uchybień, kolejna zostaje wyznaczona za 2 lata. Kiedy jednak organ inspekcyjny będzie miał uzasadnione wątpliwości co do prawidłowego funkcjonowania gospodarstwa, kontrole mogą odbywać się kilka razy w roku.

Ocena działania podmiotów prowadzacych działalność w ramach sprzedaży bezpośredniej

Zgodnie z deklaracją podaną w Głównym Inspektoracie Weterynarii [18] w ramach sprzedaży bezpośredniej w powiecie tczewskim 9 podmiotów oferuje jaja konsumpcyjne, jeden z nich również drób. Największą grupę stanowią podmioty, które sprzedają nieprzetworzone produkty pszczele -18 podmiotów. Dwa podmioty zajmują się sprzedażą produktów rybołówstwa (rys. 2).

Z badań ankietowych wynika, że respondenci zajmują się bezpośrednią sprzedażą miodu, jaj i drobiu zgodnie z podaną deklaracją. Jeden respondent wskazał inny pro- 
dukt przeznaczony do sprzedaży niż ten, który został zgłoszony we wniosku rejestracyjnym (mleko).

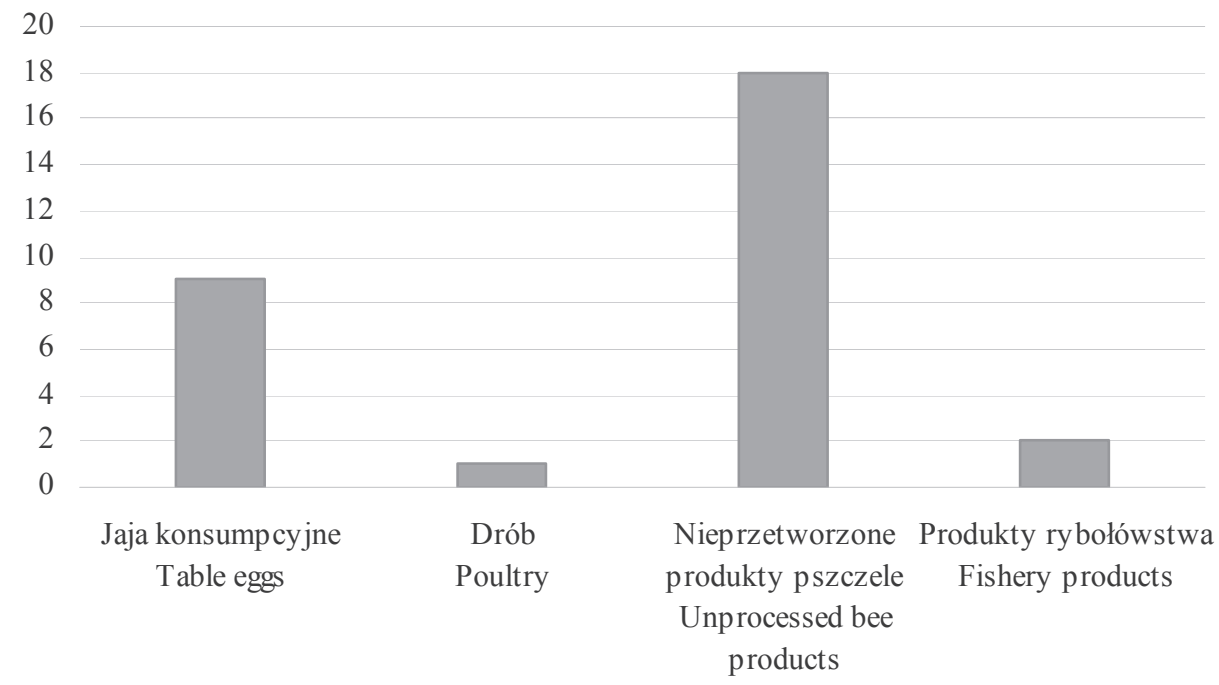

Rys. 2. Podmioty działające w ramach sprzedaży bezpośredniej w powiecie tczewskim

Fig. 2. Entities operating within direct sales in Tczew Poviat

Źródło / Source: opracowanie własne / the author's own study

Pierwsze pytanie kwestionariusza dotyczyło daty rejestracji działalności sprzedaży bezpośredniej. Po zmianie w 2016 r. przepisów dotyczących sprzedaży bezpośredniej 4 podmioty zdecydowały się zarejestrować działalność. W 2013 roku działalność zrejestrowały 2 podmioty, jeden w 2012, a pozostali - przed 2010 rokiem. Tylko jeden respondent wskazał datę dzienną, pozostali podawali jedynie rok (rys. 3).

Wpływy ze sprzedaży bezpośredniej u połowy respondentów stanowią główne źródło dochodu, co związane jest z roczną wielkością sprzedaży, która wynosi od jednej do pięciu ton miodu oraz ok. 90 tys. jaj i ok. 1000 sztuk drobiu rocznie. U pozostałych $50 \%$ respondentów sprzedaż bezpośrednia jest działalnością poboczną, a wielkość sprzedaży nie przekracza 18 tys. litrów mleka, 250 litrów miodu rocznie i 250 sztuk jaj dziennie.

Zdecydowana większość podmiotów sprzedaje swoje produkty w miejscu ich wytwarzania. Drugim powszechnym miejscem dystrybucji produktów są bazary i targowiska. Uczestnictwo w festynach zadeklarowały tylko dwa podmioty. Jeden podmiot wskazał, że ma stałego odbiorcę, który odkupuje od niego całość towaru. Innym sposobem zbycia produktów, wskazanym przez jednego producenta, jest sprzedawanie ich w sklepie związkowym. 
4

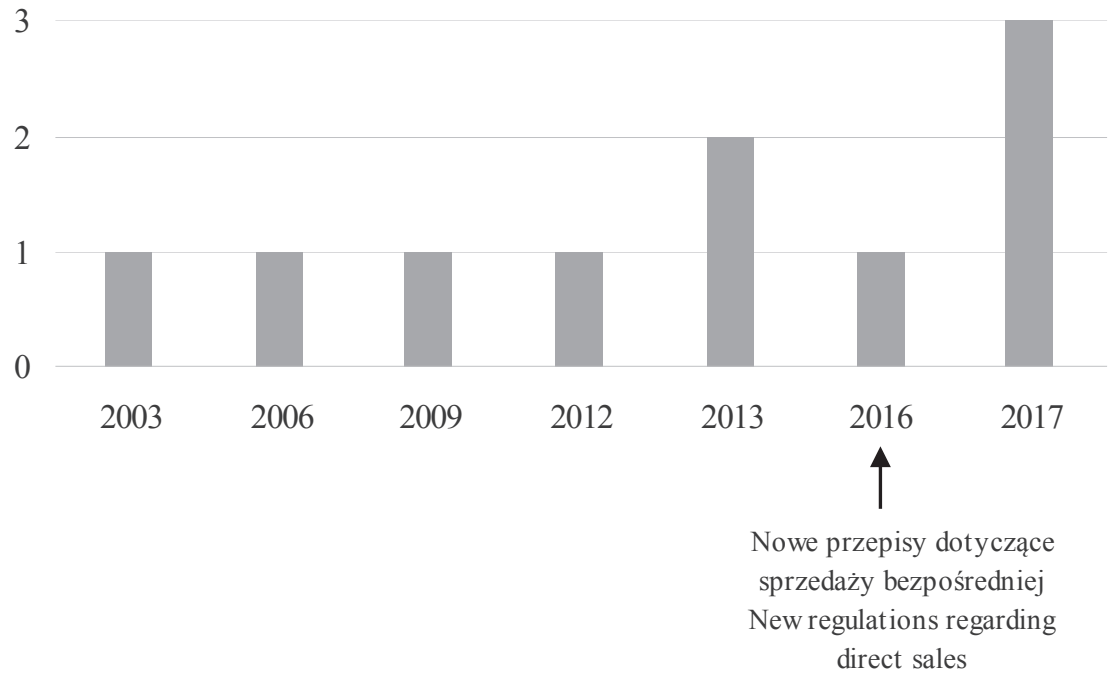

Rys. 3. Data rejestracji działalności podmiotów sprzedaży bezpośredniej

Fig. 3 Registration date of activities run by entities within direct sales

Źródło / Source: opracowanie własne / the author's own study

Producenci odpowiadają za bezpieczeństwo zdrowotne żywności, jednak wszystkie organizacje rządowe i pozarządowe powinny ponosić odpowiedzialność za skuteczne i sprawne koordynowanie zapewnienia jakości zdrowotnej żywności. Zadaniem technologów żywności jest oszacowanie ryzyka związanego ze spożyciem różnego rodzaju żywności. Zadanie to jest o tyle trudne, że żywność jest bardzo różnorodna, więc zagrożenia $\mathrm{z}$ nią związane zmieniają się $\mathrm{w}$ zależności od rodzaju produktu spożywczego [4].

Wszyscy ankietowani zgodnie oświadczyli, że ich produkty spełniają wymagania stawiane tego rodzaju produktom. Zapewniali też, że są to produkty bezpieczne oraz wysokiej jakości. Producenci zadeklarowali, że zapewniają bezpieczeństwo wytwarzanym produktom bez względu na to, jakie to są produkty, przede wszystkim poprzez stosowanie jednorazowych opakowań, a także poprzez zastosowanie się do wymagań oraz zaleceń Inspekcji Weterynaryjnej (rys. 4).

Respondenci podkreślali, że najważniejszym sposobem zapewnienia wysokiej jakości produktu podczas konfekcjonowania miodu jest zastosowanie jednorazowych szklanych opakowań, jak i odpowiednio wyposażona pracowania. Zagwarantowanie jakości oraz bezpieczeństwa jaj uzyskiwane jest nie tylko poprzez stosowanie opako- 
wań, ale również przez zastosowanie odpowiedniego pokarmu dla ptactwa. Producenci stosują pasze ekologiczne lub zboże własnej produkcji.

Opakowanie / Packaging

Odpowiednie jednorazowe opakowania szklane Suitable disposable glass packaging

Stosowanie zaleceń IW Application of IW recommendations

Produkcja zgodna $\mathrm{z}$ wymagany mi procedurami Production in accordance with the required procedures

Odpowiednio wyposażona pracownia, punkt odbioru

Properly equipped workshop, collection point

Tradycyjna metoda produkcji

Traditional production method

Stosowanie pasz ekologicznych, własnego zboża Use of organic feeds, own grain

Chłodnie, sprzedaż żywy ch ryb Cold stores, sale of live fish

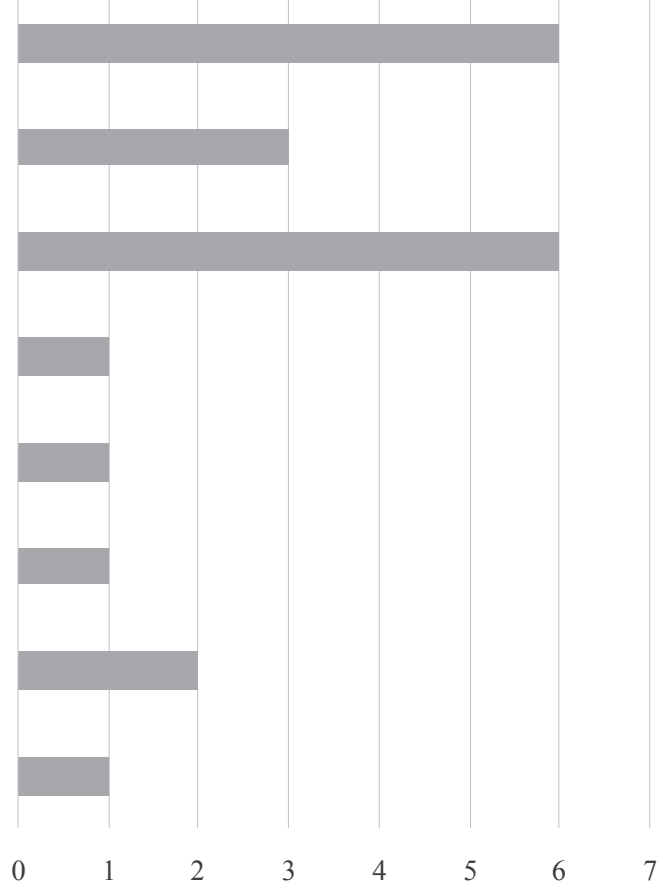

Rys. 4. Sposoby zapewnienia bezpieczeństwa wytwarzanym produktom

Fig. 4. Methods to ensure safety of manufactured products Źródło / Source: opracowanie własne / the author's own study

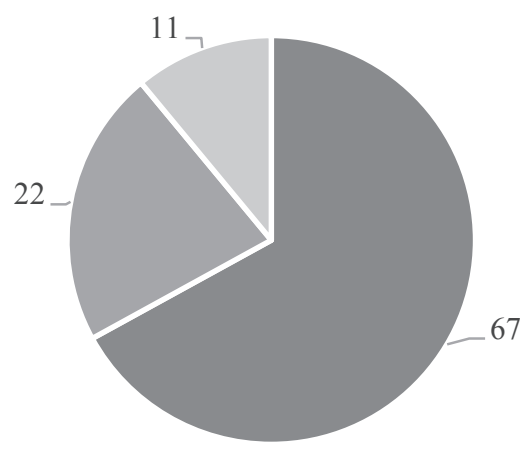
once a year

- dwa razy w roku twice a year

- raz na trzy lata once per three years

Rys. 5. Częstotliwość kontroli Inspekcji Weterynaryjnej [\%]

Fig. 5. Frequency of controls by Veterinary Inspection [\%] Źródło / Source: opracowanie własne / the author's own study 
Optymalny dla konsumentów termin przydatności do spożycia, jako gwarancja wygody użytkowania, mogą zapewnić naturalne metody utrwalania żywności, takie jak mrożenie oraz odpowiednie opakowanie [1]. Jako sposób zapewnienia bezpieczeństwa ankietowani wskazywali również zastosowanie się do wytycznych i zaleceń pokontrolnych Inspektorów Weterynarii. U 67 \% badanych taka kontrola odbywa się raz w roku (rys. 5), u $22 \%$ respondentów - dwa razy w roku, a u pozostałych $11 \%$ wizytacja odbywa się raz na trzy lata. Najczęściej kontrole odbywają się u producentów jaj i u producentów miodu, których działalność jest głównym źródłem dochodu.

\section{Wnioski}

1. Przepisy dotyczące podmiotów prowadzących produkcję we własnych gospodarstwach i sprzedaż bezpośrednią wytworzonej żywności wydają się być bardzo korzystne dla rolników chcących rozwijać działalność w tym zakresie.

2. Wykazano, że w przypadku żywności pochodzenia zwierzęcego zarówno służby odpowiedzialne za bezpieczeństwo żywności, jak i jej producenci stosują się do zaleceń zawartych w aktach prawnych.

3. Sprzedaż bezpośrednia może stanowić główne źródło dochodu, ale bywa również działalnością poboczną.

4. Według deklaracji producentów żywność wytworzona w ich gospodarstwach jest bezpieczna, spełnia wymagania stawiane tego rodzaju produktom oraz jest wysokiej jakości.

5. Najczęściej produkty te sprzedawane są w miejscu ich wytwarzania. Miejscami, gdzie konsument może poznać i zakupić taką żywność są również bazary, targowiska i festyny.

6. Producenci żywności pochodzenia zwierzęcego są regularnie kontrolowani przez Inspektorów Weterynarii i stosują się do zaleceń pokontrolnych.

7. Odpowiednio skonstruowany system prawny, system kontroli oraz postępowanie producentów powinny zapewnić bezpieczeństwo żywności pochodzenia zwierzęcego sprzedawanej w systemie bezpośrednim.

\section{Literatura}

[1] Gutkowska K., Żakowska-Biemans S., Sajdakowska M.: Preferencje konsumentów w zakresie możliwych do zastosowania innowacji w produktach tradycyjnych. Żywność. Nauka. Technologia. Jakość, 2009, 3 (64), 115-125.

[2] Kapała A., Kalinowski J., Minta S.: Sprzedaż bezpośrednia w Polsce na przykładzie produktów pochodzenia zwierzęcego. Rocz. Nauk. SERiA, 2015, XVII (4), 116-122.

[3] Kołożyn-Krajewska D.: Bezpieczeństwo zdrowotne produktów tradycyjnych. W: Tradycyjne i regionalne technologie oraz produkty w żywieniu człowieka. Red. Z.J. Dolatowski i D. KołożynKrajewska. Wyd. Nauk. PTTŻ, Kraków 2008, ss. 59-72. 
[4] Kołożyn-Krajewska D., Sikora T.: Ocena ryzyka zdrowotnego żywności. Żywność. Nauka. Technologia. Jakość, 2001, 3 (28) Supl., 150-161.

[5] Rozporządzenie (WE) nr 178/2002 Parlamentu Europejskiego i Rady z dnia 28 stycznia 2002 r. ustanawiające ogólne zasady i wymagania prawa żywnościowego, powołujące Europejski Urząd ds. Bezpieczeństwa Żywności oraz ustanawiające procedury w zakresie bezpieczeństwa żywności. Dz. U. L 31, ss. 1-24, z 01.02.2002.

[6] Rozporządzenie (WE) nr 852/2004 Parlamentu Europejskiego i Rady z dnia 29 kwietnia 2004 r. w sprawie higieny środków spożywczych. Dz. U. L 139, ss. 1-54, z 30.04.2004.

[7] Rozporządzenie (WE) nr 853/2004 Parlamentu Europejskiego i Rady z dnia 29 kwietnia 2004 r. ustanawiające szczególne przepisy dotyczące higieny w odniesieniu do żywności pochodzenia zwierzęcego. Dz. U. L 139, ss. 55-205, z 30.04.2004.

[8] Rozporządzenie (WE) nr 854/2004 Parlamentu Europejskiego i Rady z dnia 29 kwietnia 2004 r. ustanawiające szczególne przepisy dotyczące organizacji urzędowych kontroli $\mathrm{w}$ odniesieniu do produktów pochodzenia zwierzęcego przeznaczonych do spożycia przez ludzi. Dz. U. L 139, ss. 206-320, z 30.04.2004.

[9] Rozporządzenie Ministra Zdrowia z dnia 6 czerwca 2007 r. w sprawie dostaw bezpośrednich środków spożywczych. Dz. U. 2007 r. Nr 112, poz. 774.

[10] Rozporządzenie wykonawcze Komisji (UE) nr 931/2011 z dnia 19 września 2011 r. w sprawie wymogów dotyczących możliwości śledzenia ustanowionych Rozporządzeniem (WE) nr 178/2002 Parlamentu Europejskiego i Rady w odniesieniu do żywności pochodzenia zwierzęcego. Dz. U. L 242, ss. 2-3, z 20.09.2011.

[11] Rozporządzenie Ministra Rolnictwa i Rozwoju Wsi z dnia 30 września 2015 r. w sprawie wymagań weterynaryjnych przy produkcji produktów pochodzenia zwierzęcego przeznaczonych do sprzedaży bezpośredniej. Dz. U. 2015 r., poz. 1703.

[12] Rozporządzenie Ministra Rolnictwa i Rozwoju Wsi z dnia 15 grudnia 2016 r. w sprawie sposobu ustalania weterynaryjnego numeru identyfikacyjnego. Dz. U. 2016 r., poz. 2161.

[13] Sieczko A., Sieczko L., Parzonko A.J.: Regionalne zróżnicowanie sprzedaży bezpośredniej produktów pochodzenia zwierzęcego w Polsce. Rocz. Nauk. SERiA, 2016, 103 (4), 69-77.

[14] Surówka K., Rzepka M., Maciejaszek I., Tesarowicz I., Zawiślak A., Banaś J.: Jakość i bezpieczeństwo serków wędzonych wytwarzanych w regionie Podhala. Żywność. Nauka. Technologia. Jakość, 2016, 4 (107), 102-114.

[15] Ustawa z dnia 29 stycznia 2004 r. o Inspekcji Weterynaryjnej - tekst jednolity. Dz. U. 2018 r., poz. 1557.

[16] Ustawa z dnia 16 grudnia 2005 r. o produktach pochodzenia zwierzęcego - tekst jednolity. Dz. U. 2017 r., poz. 242.

[17] Ustawa z dnia 25 sierpnia 2006 r. o bezpieczeństwie żywności i żywienia - tekst jednolity. Dz. U. 2018 r., poz. 1541.

[18] Wykaz zakładów prowadzących sprzedaż bezpośrednią. [online]. Główny Inspektorat Weterynarii. Dostęp w Internecie [3.07.2018r]: https://pasze.wetgiw.gov.pl/spi/demosb/index.php

\title{
DIRECT SALES AND FOOD SAFETY OF ANIMAL ORIGIN EXEMPLIFIED BY PRACTICES IN TCZEW POVIAT
}

\author{
$\mathrm{Sum}$ mary
}

In the food market highly processed products predominate. The wide range of food products causes the consumers to be more demanding and to make purchases with better awareness. They seek sensory 
attractive food from a verified source and food products, which meet safety requirements, including those referring to additional substances and flavours used, their permitted amounts, levels of contaminants, pesticide residues, food irradiation conditions and actions taken during manufacturing or food marketing the purpose of which is primarily to ensure that foods are safe for human health and life. Those requirements should also be met by foods sold in a direct sales system. According to the definition, such foods are made from raw materials owned by an entity manufacturing products intended for direct sale. The objective of the paper was to analyze formal requirements concerning direct sales of food products in order to determine whether or not the current legal system ensures the safety of directly sold foods. An employee with the Poviat Veterinary Inspectorate in Tczew was interviewed and a group of 10 producers from the Tczew Poviat were surveyed; the survey was a pilot one and the respondents were selected on purpose. The respondents accounted for $34 \%$ of the manufacturers of food of animal origin that was sold directly. The questionnaire consisted of questions about the registration date of manufacturing activities, methods of ensuring safety of products being manufactured and the frequency of controls run by the Veterinary Inspection. It was shown that both the legal system, the manufacturing method and the control system guaranteed the safety of this type of food in the group surveyed. The conclusions from the pilot survey will be used to perform similar surveys on a larger, representative group of respondents.

Key words: : direct sales, ensuring food safety, control, Veterinary Inspection

ORCID IP

Agnieszka Palka 0000-0002-5557-9983

Aleksandra Wilczyńska 0000-0003-4434-0819 